\title{
Challenges of solar and renewable energy technologies (Presentation Video)
}

\section{Thomas Bialek}

Thomas J. Bialek, "Challenges of solar and renewable energy technologies (Presentation Video)," Proc. SPIE 8824, Next Generation (Nano) Photonic and Cell Technologies for Solar Energy Conversion IV, 88241A (25 September 2014); doi: 10.1117/12.2050955

SPIE Event: SPIE Solar Energy + Technology, 2013, San Diego, California, United States 


\title{
Challenges of Solar and Renewable Energy Technologies (Presentation Video)
}

\author{
Thomas J. Bialek, San Diego Gas \& Electric Co. (United States)
}

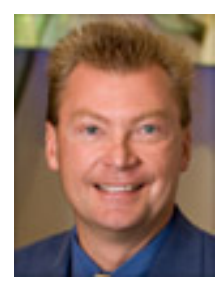

\begin{abstract}
California's aggressive energy policy goals include a Renewable Portfolio Standard, RPS, which requires 33\% of energy produced must come from renewable resources by 2020. Additionally, SDG\&E as of the end of March 2013 has approximately 23,000 installations of rooftop photovoltaics with a nameplate capacity $171 \mathrm{MW}$ that do not count towards the RPS goal. Renewable resources are intermittent power generators that introduce new challenges to planning, designing and operating a utility grid. SDG\&E has been developing solutions to these challenges and will discuss this topic further in the plenary talk.
\end{abstract}

View presentation video on SPIE's Digital Library: http://dx.doi.org/10.1117/12.2050955

Next Generation (Nano) Photonic and Cell Technologies for Solar Energy Conversion IV, edited by Oleg V. Sulima, Gavin Conibeer, Proc. of SPIE Vol. 8824, 88241A - (C) 2013 SPIE

CCC code: $0277-786 \mathrm{X} / 13 / \$ 18 \cdot$ doi: $10.1117 / 12.2050955$

Proc. of SPIE Vol. $882488241 \mathrm{~A}-1$ 